\title{
BERMAIN DAN BELAJAR BAHASA INGGRIS BERBASIS PENDIDIKAN KARAKTER
}

\author{
Samuel Gunawan \\ Jenny M. Djundjung \\ Meilinda \\ Fakultas Sastra, Universitas Kristen Petra \\ Л. Siwalankerto 121-131, Surabaya 60236 \\ Email: samgun@petra.ac.id
}

\begin{abstract}
Abstrak: Kegiatan Pengabdian kepada Masyarakat (abdimas) "Kompetensi Komunikasi Bahasa Inggris Berbasis Pengembangan Karakter pada Kelompok Belajar Anak di Kelurahan Dr. Soetomo, Surabaya”, telah dilaksanakan pada bulan September dan Oktober 2013. Kegiatan ini bertujuan untuk membantu mengangkat kawasan ini agar menjadi kawasan yang ikut mewujudkan Surabaya benar-benar sebagai kota layak dan ramah anak. Dalam pelaksanaannya, melibatkan tidak kurang dari 50 orang anak asuh Pendidikan Anak Usia Dini (PAUD) RW 3, 6 dosen, 16 mahasiswa, dan 8 bunda PAUD setempat. Kegiatan Abdimas ini menghasilkan luaran, antara lain: materi pengembangan kompetensi komunikasi Bahasa Inggris berbasis pengembangan karakter; penguatan kelembagaan PAUD RW 3, Kelurahan Dr. Soetomo, Surabaya; penguatan tenaga pendamping PAUD komunitas setempat; kegiatan bermain dan belajar untuk pengembangan kompetensi komunikasi Bahasa Inggris berbasis pengembangan karakter di PAUD setempat; unjuk kebolehan kompetensi komunikasi Bahasa Inggris berbasis pengembangan karakter. Pada akhirnya, kegiatan ini telah membawa manfaat memberi penguatan, pemberdayaan SDM, dan pencerahan kepada segenap pihak yang secara langsung dan tidak langsung terlibat dalam kegiatan ini.
\end{abstract}

Kata kunci: Bahasa Inggris, pendidikan karakter, Bahasa Inggris dan Karakter.

\begin{abstract}
The Community Service Project funded by the Higher Education IbM grant entitled "English Communication Competence for Character Development in the Children Study Group in Kelurahan Dr Soetomo, Surabaya", was carried out in September and October 2013. The project aimed at helping to uplift the region to be a participating region in support of Surabaya as a child-friendly and decent city. In implementation, the project has been attended by no less than 50 foster children of the local Early Childhood Education (ECE), RW 3, 6 lecturers, 16 students, and 8 local ECE attendants. The project has contributed some results, such as: materials for developing English communication competence in support of character development; institutional strengthening of the local ECE, RW 3, Kelurahan Dr. Soetomo, Surabaya; empowering the competence of the local ECE attendants; facilitating playing and learning activities for the development of English communication competence for character development at the local ECE; demonstrations of English communication competence based on character development. Finally, the project has contributed the strengthening and empowering of the human resources, and provided some insight to those who have directly and indirectly participated in the project.
\end{abstract}

Keywords: English, character education, English Language and Character

\section{PENDAHULUAN}

Surabaya sebagai kota metropolitan terbesar kedua di Indonesia yang berkembang dengan pesat tak luput dari permasalahan carut marut lingkungan kehidupan sosial warga masyarakat. Hal itu terjadi karena pertumbuhan kota yang pesat, namun tidak merata dan berkeseimbangan, sehingga menciptakan situasi lingkungan kehidupan sosial yang tidak kondusif ke arah peningkatan kualitas hidup yang layak, khususnya bagi pertumbuhan dan perkembangan anak dari 0-18 tahun. Lingkungan sosial yang kurang menguntungkan demikian itu yang potensial memerosotkan kualitas hidup pada pertumbuhan dan perkembangan anak, khususnya di daerah-daerah kantong "ketertinggalan" di jantung kota Surabaya. 
Pada th 2011, tepat pada Hari Anak-anak, Surabaya meraih penghargaan sebagai Kota Layak Anak (KLA) karena dianggap memenuhi syarat indikator umum dan persyaratan lima kluster terutama mengenai pemenuhan hak anak-anak sebagai implementasi "Convention of the Right of the Child" (CRC) dan "World Fit for the Children" (WFC). Pemerintah Kota Surabaya sudah nampak berupaya ke arah terwujudnya KLA, namun kalau ditelusuri, sebenarnya masih banyak "kantongkantong ketertinggalan" yang masih masih harus dibenahi, yang memerlukan perhatian dan tindakan nyata segenap pemangku kepentingan kota demi kelangsungan perkembangan kota yang berkelanjutan. Tak pelak kalau Ketua Komisi D, Baktiono melontarkan kritiknya di depan wartawan di kantor DPRD Surabaya [1]. Menurut dia predikat yang diraih Surabaya sebagai "Kota Layak Anak" itu dinilainya sangat kontradiktif mengingat masih banyak kepentingan anak-anak terabaikan, misalnya masih tingginya angka kekerasan seksual hingga trafficking terhadap pelajar. Tidak bisa dipungkiri bahwa angka kekerasan yang terjadi pada anak di Surabaya adalah yang tertinggi di Jawa Timur. Sejak Januari hingga Oktober 2011, Lembaga Perlindungan Anak (LPA) Jatim mencatat ada 130 kasus yang masuk [2].

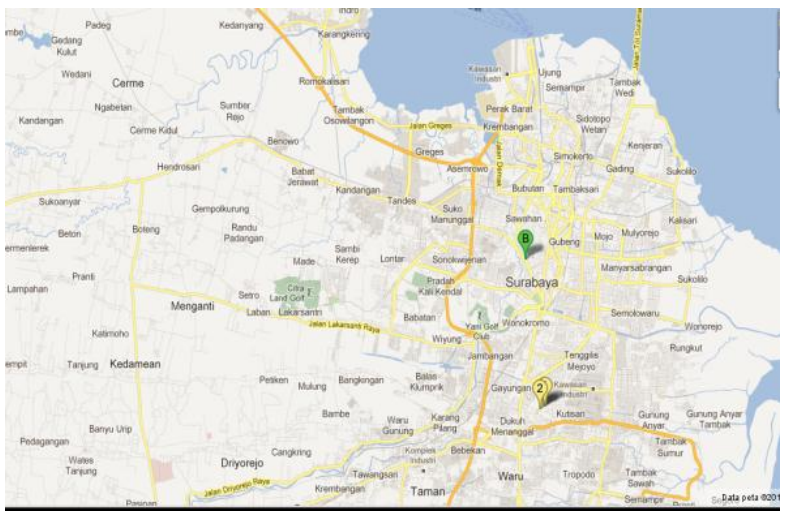

Gambar. 1. Lokasi Pengabdian kepada Masyarakat di jantung kota Surabaya

Di antara perkampungan kota Surabaya Pusat terdapat RW 3 yang terletak di lingkup kelurahan DR. Soetomo, Kecamatan Tegalsari, yang telah dijadikan kelompok sasaran abdimas yang dilaporkan di sini. RW 3 tersebut sebagai suatu komunitas warga menyimpan kekhususan lingkungan hidup keseharian: dari yang kondusif sampai yang kurang kondusif ke arah kota layak anak. Di daerah ini antara Wahana Visi Indonesia - mitra I pelaksanaan abdimas ini dan unsur pemerintahan daerah yang dinyatakan oleh perhatian lurah setempat, sebagai mitra II pelaksanaan abdimas ini - telah terjalin kerjasama untuk membangun lingkungan hidup yang lebih ramah dan layak bagi anak. Dapat dicontohkan hasil kerjasama itu telah membuahkan gerakan PAUD yang swadaya dan berbasis masyarakat setempat seperti halnya yang telah berjalan di Balai RW 3 setempat.

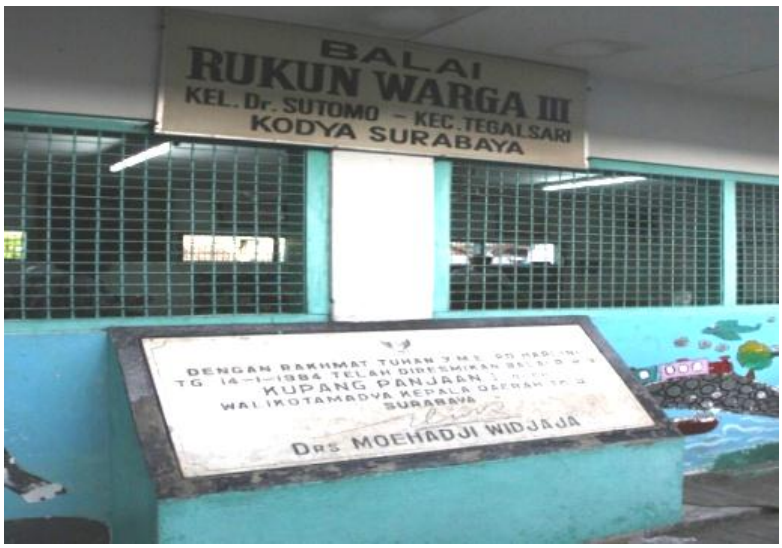

Gambar 2. Balai RW 3, Kelurahan Soetomo, Surabaya

Di daerah khalayak sasaran ini masih perlu dirintis dan ditumbuhkembangkan beberapa kegiatan bervariasi, yang antara lain seperti dilaksanakan dalam Pengabdian kepada Masyarakat ini, yang nyata-nyata bisa membantu mengangkat kawasan ini sebagai kawasan yang ikut mewujudkan Surabaya benar-benar sebagai Kota Layak dan ramah Anak.

\section{PERMASALAHAN MITRA}

Permasalahan yang dihadapi oleh mitra adalah: bagaimana menghadirkan kondisi sosial yang kondusif bagi perkembangan anak, khususnya yang menyangkut penguatan kelembagaan wadah kegiatan komunitas yang memperhatikan kepentingan anak, lingkungan keluarga dan pengasuhan alternatif, pendidikan dan pemanfaatan waktu luang anak, hak sipil dan kebebasan anak.

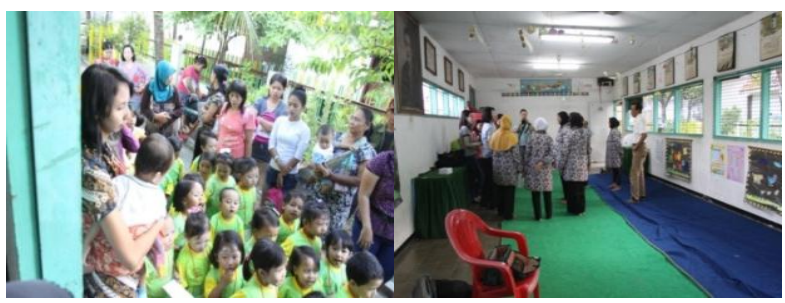

Gambar 3. Persiapan mengenai kegiatan abdimas di PAUD RW 3

\section{METODE PELAKSANAAN}

Tim abdimas dengan mensinergikan keahlian, pengalaman dan dedikasinya berusaha menggerakkan kekuatan secara bottom up dalam lingkup terbatas untuk melakukan tindakan konkrit pendampingan dan pemberdayaan komunitas RW 3 di Kelurahan Dr. Soetomo melalui langkah-langkah konkrit sbb.: 
1. Memberi penguatan kelembagaan Kelompok Bermain Anak (KBA) PAUD RW 3, Kelurahan Dr. Soetomo, sesuai kegiatan abdimas yang dijalankannya.

2. Mempersiapkan, memberi pelatihan dan mengikutsertakan (training of trainer) para bunda PAUD, pendamping/calon pendamping dari komunitas setempat dan para mahasiswa dalam kegiatan abdimas. Dengan demikian dirintis terbinanya potensi untuk kegiatan berkelanjutan yang didukung langsung oleh komunitas khalayak sasaran, sekaligus juga merupakan ajang bagi para mahasiswa untuk mengasah kepekaan sosial mereka.

3. Menginisiasi kegiatan pendampingan dalam situasi bermain dan belajar yang sangat informal secara bottom up, yang bertujuan mengembangkan kompetensi komunikasi Bahasa Inggris anak layan berbasis pengembangan karakter mereka dalam rangka ikut menciptakan peningkatan kualitas lingkungan keluarga dan pengasuhan alternatif yang kondusif bagi tumbuh kembangnya anak dari usia 3-6 tahun.

4. Menyediakan kegiatan positif-konstruktif dalam memanfaatkan waktu luang anak-anak. Dalam situasi bermain, anak didampingi menciptakan suasana belajar yang informal dan sekaligus mengembangkan karakter positif sebagai life skill yang penting bagi masa depan mereka. Kegiatan ini diharapkan bisa berjalan secara berkelanjutan sesuai dengan tingkat dan irama perkembangan anak-anak.

5. Menumbuhkembangkan kemampuan anak untuk memiliki karakter yang kuat, tampil penuh percaya diri, ekspresif, yang sangat vital bagi terwujudnya pemenuhan hak-hak dan kebebasannya untuk menggapai masa depan yang lebih baik.

Adapun bentuk kegiatan abdimas yang dilaksanakan adalah menyelenggarakan kegiatan membangun komunikasi Bahasa Inggris berbasis Pengembangan Karakter pada anak-anak yang ikut kegiatan PAUD RW 3 di Kelurahan Dr. Soetomo. Kegiatan abdimas ini diikuti tak kurang dari 50 anak dari RW 3 dan sekitarnya.

Kepada anak-anak telah diberikan pendampingan dalam kegiatan bermain dan belajar di PAUD khalayak sasaran yang sifatnya tidak formal dalam suasana bermain-main namun diciptakan suasana membangun dasar-dasar yang kokoh berkomunikasi dalam Bahasa Inggris sehingga anak-anak, sesuai tingkat perkembangan dan usianya, mampu mengungkapkan pikiran, isi hati dan perasaan secara lugas dan jelas, yang secara berangsurangsur diungkapkan dalam Bahasa Inggris. Hal ini sekaligus memberi mereka 2 (dua) jenis softskills yang sangat dibutuhkan untuk menggapai masa depan yang lebih baik, yaitu kompetensi berbahasa Inggris dan kemampuan membangun karakter positif yang kuat.

Tim abdimas bermaksud mewujudkan kegiatan konkrit berbasis komunitas setempat khalayak sasaran. Dengan adanya dukungan komunitas khalayak sasaran, diharapkan akan terjadi penguatan kelembagaan PAUD setempat dan peningkatan wawasan dan keterampilan para bunda/tenaga pendamping yang berasal dari khalayak sasaran, sehingga kegiatan abdimas yang diusulkan nantinya dapat berjalan secara berkelanjutan; dan bahkan bisa ditularkan di lingkup PAUD lainnya, khususnya di daerah-daerah "kantong-kantong ketertinggalan" lainnya.

Secara selektif proses pendidikan karakter pada kegiatan Abdimas ini didasarkan pada totalitas psikologis yang mencakup seluruh potensi individu anak (kognitif, afektif, psikomotorik) dan fungsi totalitas sosio kultural dalam konteks interaksi dalam keluarga, satuan pendidikan, dan masyarakat (cf. Lickona, 1991) [3]. Totalitas psikologis dan sosiokultural dapat dikelompokkan secara selektif sebagaimana yang digambarkan dalam bagan berikut [4]:

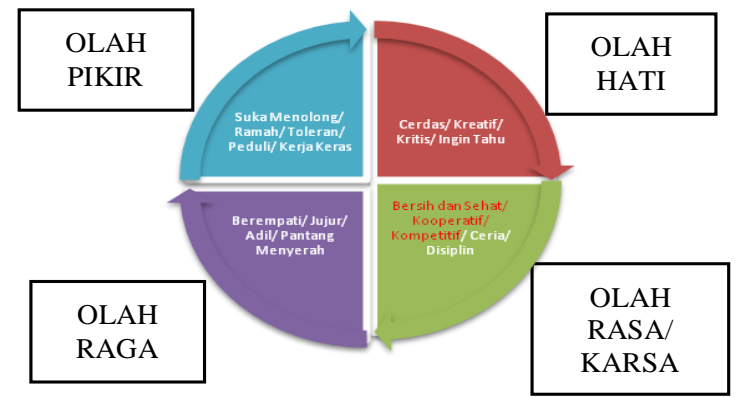

Gambar 4. Totalitas Konfigurasi Pendidikan Karakter

Konfigurasi karakter dalam kontek totalitas proses psikologis dan sosial-kultural dapat dikelompokkan dalam: (1) Olah Hati (spiritual \& emotional development); (2) Olah Pikir (intellectual development); (3) Olah Raga dan kinestetik (physical \& kinesthetic development); dan (4) Olah Rasa dan Karsa (affective and creativity development).

Pembentukan karakter adalah sangat penting sehingga anak-anak diharapkan akan didampingi melalui situasi yang sangat kondusif untuk mengembangkan karakter yang kuat. Karakter yang demikian inilah yang akan membentuk insan-insan yang tidak mudah menyerah pada sekumpulan realitas yang mengkondisi dirinya; insan yang sanggup membangun dan merancang masa depannya sendiri dan tidak mau menyerah pada kondisi yang menghambat pertumbuhannya ([5]. 


\section{HASIL DAN PEMBAHASAN}

Kegiatan pengabdian kepada masyarakat telah dilaksanakan dengan baik dari tgl 24 September s/d 29 Oktober 2013. Kegiatan tersebut telah memberikan hasil berupa, antara lain, penguatan kelembagaan Kelompok Bermain Anak PAUD RW 3, penguatan SDM bunda PAUD RW 3, dan pendampingan dalam kegiatan bermain dan belajar Bahasa Inggris berbasis pendidikan.

\section{Penguatan kelembagaan Kelompok Bermain Anak PAUD RW3}

Kegiatan ceramah dan pencerahan mengenai "Pendidikan karakter untuk Anak-anak" untuk para bunda PAUD RW 3 Dr. Soetomo telah dilaksanakan oleh Dr. Samuel Gunawan, MA, pada tgl 20 September, 2013. Kegiatan ini diikuti oleh 8 orang bunda PAUD. Kegiatan ini dimaksudkan untuk menambah wawasan para bunda PAUD dan juga penguatan lembaga PAUD setempat.

\section{Penguatan SDM Bunda PAUD}

Dengan keikutsertaan 8 orang bunda PAUD dalam keseluruhan kegiatan "bermain dan belajar" dari abdimas yang dilaksanakan diharapkan bisa membekali dan memberi penguatan pada SDM pengasuh/pendamping kegiatan PAUD RW 3. Begitu juga dengan kehadiran para ibu dari lingkungan RW 3 diharapkan berdampak menarik minat mereka untuk ikut berpartisipasi maupun menyukseskan kegiatan PAUD setempat.

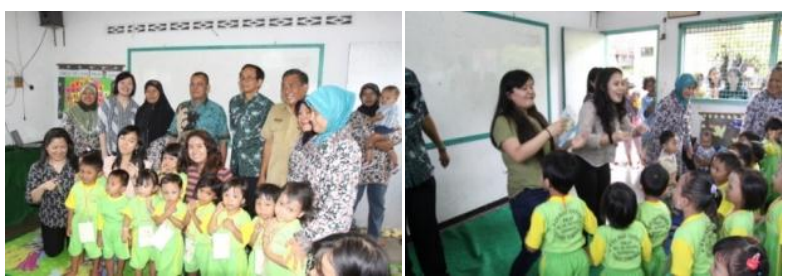

Gambar 5. Tim abdimas (dosen dan mahasiswa) bersama bunda PAUD, Ketua RW 3 dan Pak Lurah Kelurahan Dr. Soetomo bersama sebagian anak-anak asuh PAUD RW 3

\section{Pendampingan Bermain dan Belajar Bahasa Inggris Berbasis Pendidikan Karakter}

Sebelum pelaksanaan kegiatan bermain dan belajar untuk Kelompok Belajar Anak yang tergabung dalam PAUD Tunas Cempaka RW 3 sebagaimana terjadwal, terlebih dahulu seminggu sebelumnya dilaksanakan sesi khusus untuk para Bunda PAUD berupa coaching dan pencerahan perihal seluk beluk Pendidikan Karakter untuk anak usia dini pada umumnya.

Salah satu hasil pengabdian, misalnya, berupa "materi bermain dan belajar" yang khusus disusun dan dipergunakan dalam abdimas ini diserahkan kepada para Bunda PAUD setempat untuk memperkaya kegiatan bermain dan belajar di PAUD setempat. Disebut "materi bermain dan belajar" karena kepada anak-anak diajak menyanyikan teks lagu anak-anak dalam bahasa Inggris seperti dicontohkan di bawah, yang rekamannya tersedia dan dimainkan, kemudian anak-anak menyanyikan bersamaan diputarnya rekaman tersebut. Dikatakan "materi belajar" karena bahasa Inggris dalam nyanyian anak-anak tersebut bersifat tematis yang berfokus pada tata nilai pendidikan karakter. Salah satu dari materi bermain tersebut misalnya: "BERSAHABAT, MENYAYANGI TEMAN, DAN MENGHARGAI SESAMA".

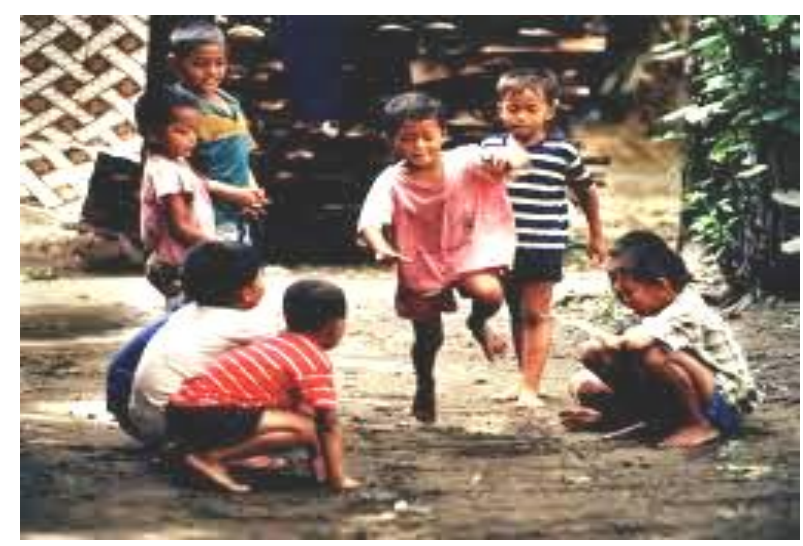

Gambar 6. Anak-anak asyik bermain

Anak-anak diajar dan diajak menyanyikan lagu "The Circle of Love". Bersamaan dengan itu diajarkan arti lirik yang berkaitan dengan tema nilai-nilai persahabatan, menyayangi teman, dan menghargai teman. Anak-anak diajak bermain-main membentuk "lingkaran kasih" yang melambangkan pertemanan mereka seperti dicontohkan.

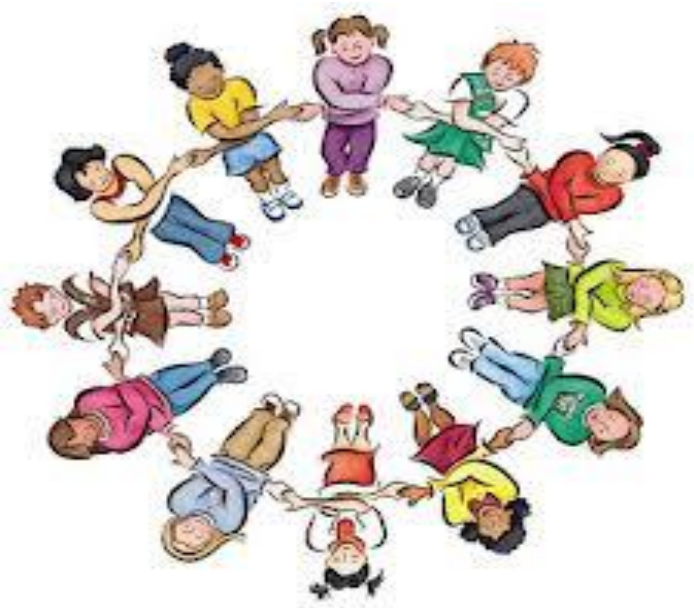

The circle of love, love grows wider and wider The circle of love, love is you and me

The circle of love, love is growing stronger The circle of love, love is free

Secara berangsur-angsur diajarkan kata-kata kunci tematis seperti "love": nilai-nilai kasih sayang dan 
empati pada kegiatan bermain dan belajar 2 . Kemudian mereka satu persatu dipotret. Pada awal kegiatan hari berikutnya - kegiatan ke-3 - mereka diajak menempelkan foto mereka pada gambar jantung hati, yang membentuk "circle of love".

Adapun ilmu terapan tepat-guna yang ditransfer dan alur pengembangan kompetensi komunikasi bahasa Inggris berbasis pengembangan karakter yang diterapkan dalam Abdimas ini dapat digambarkan pada Gambar 7.

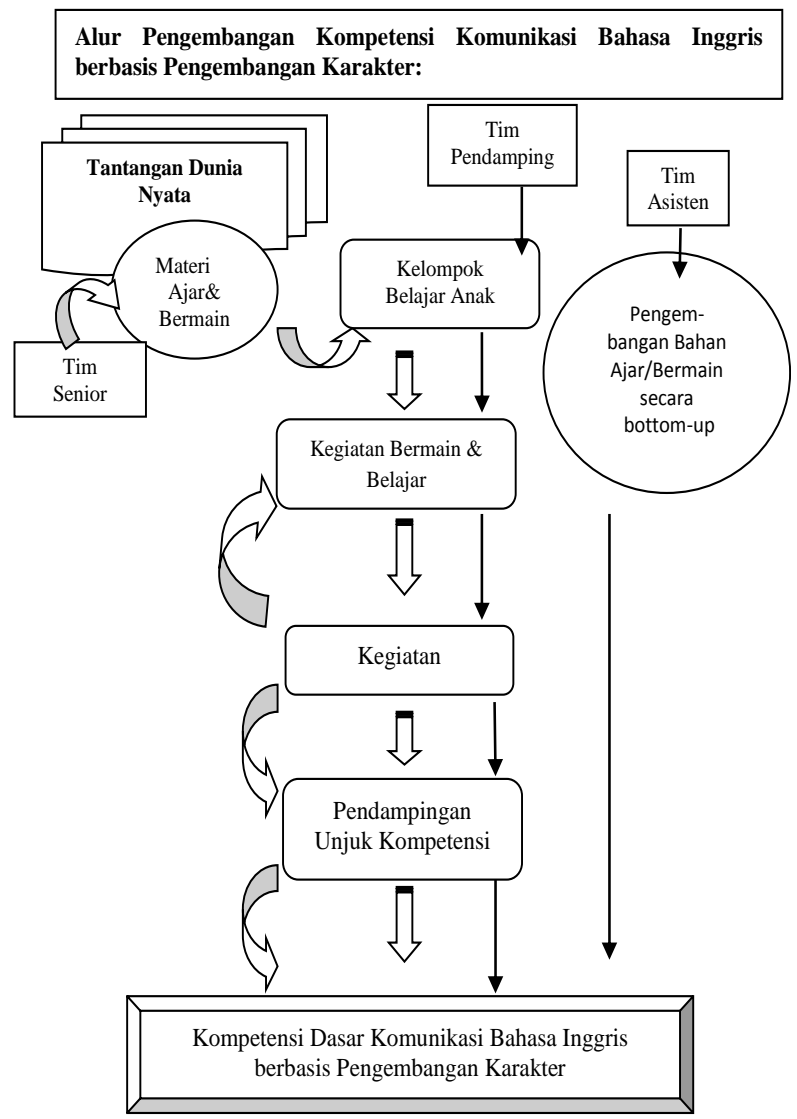

Gambar 7. Skema Alur Pengembangan Kompetensi Komunikasi Bahasa Inggris Berbasis Pengembangan Watak

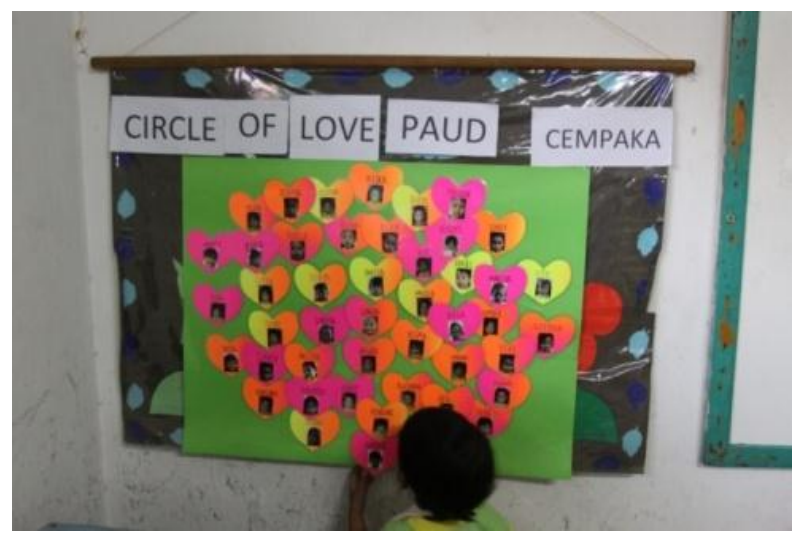

Gambar 8. Circle of love
Kegiatan tersebut di atas kemudian diikuti dengan bermain yang sifat pelengkap dan sekaligus penguatan berupa handicraft atau coloring, misalnya aktivitas yang menguatkan nilai menyayangi teman dengan mewarnai gambar "tangan" yang dipakai untuk mengekpresikan perasaan "a great hug".

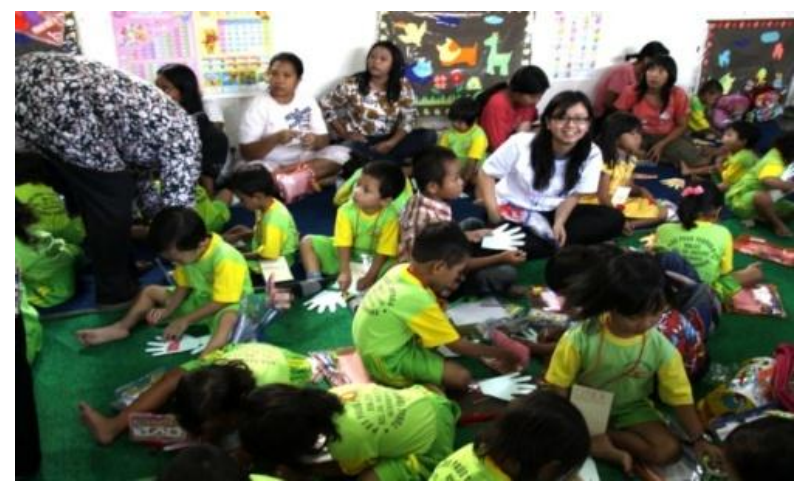

Gambar 9. Mewarnai gambar tangan yang dipakai menyatakan nilai sayang kepada teman

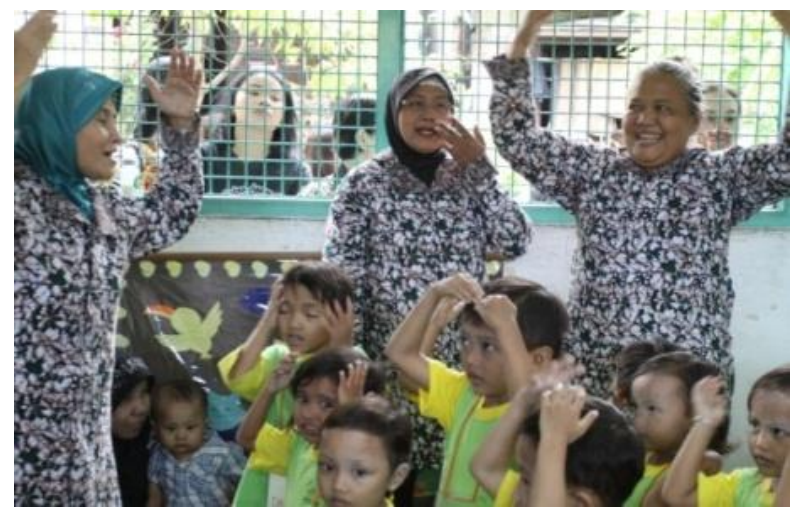

Gambar 10. Menyanyi dan meragakan: “... head, shoulders, knees and toes..."

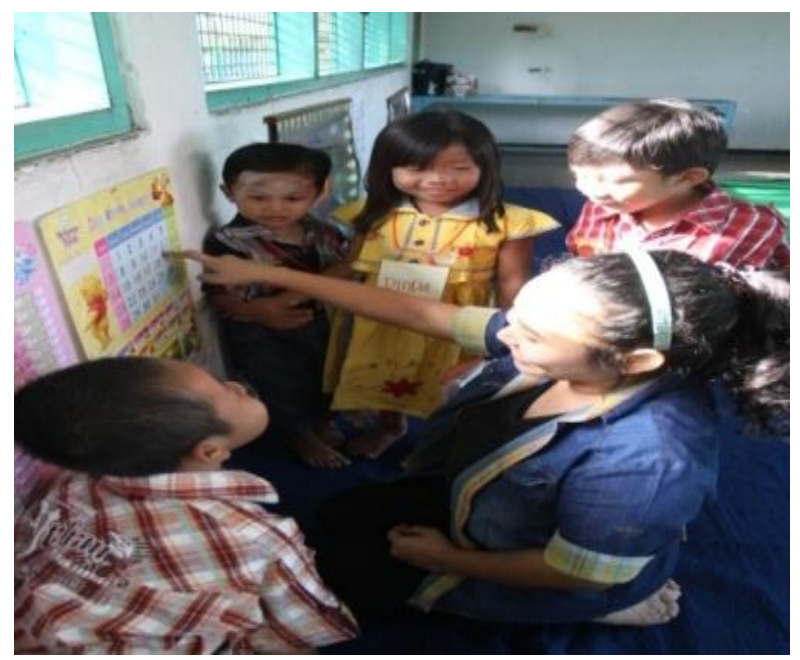

Gambar 11. Bermain dan belajar Bahasa Inggris 


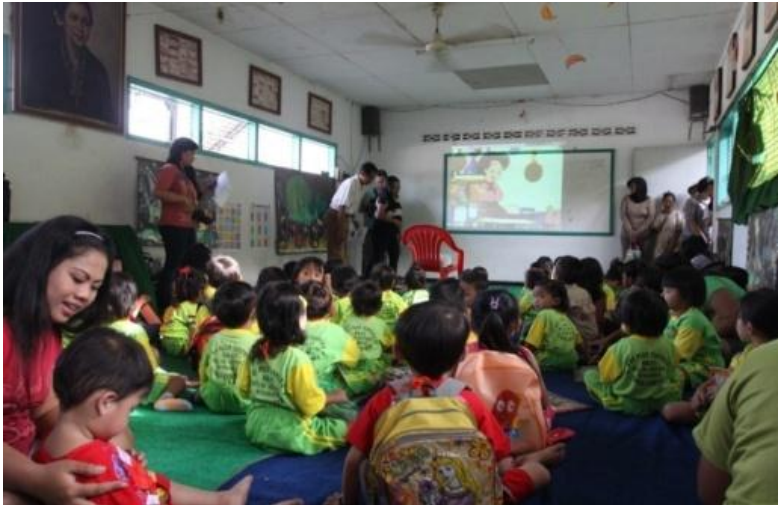

Gambar 12. Suasana ruang bermain dan belajar

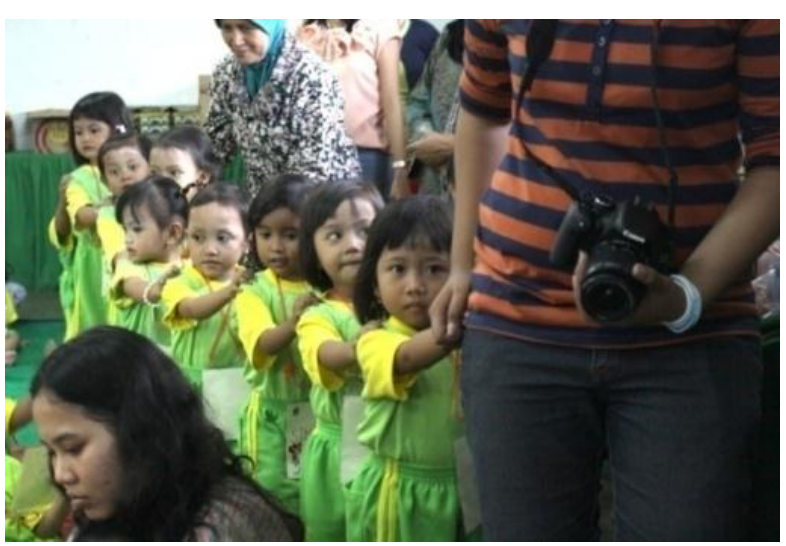

Gambar 13. Mengajar budaya antri sebelum mendapat kudapan

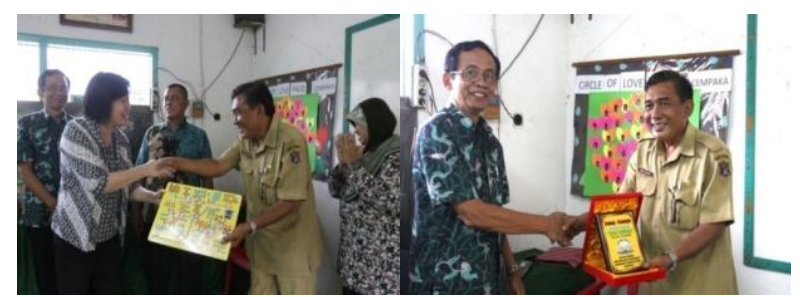

Gambar 14. Serah terima simbolis kenang-kenangan alat peraga dan plakat antara tim abdimas dan bapak lurah Kelurahan Dr. Soetomo.

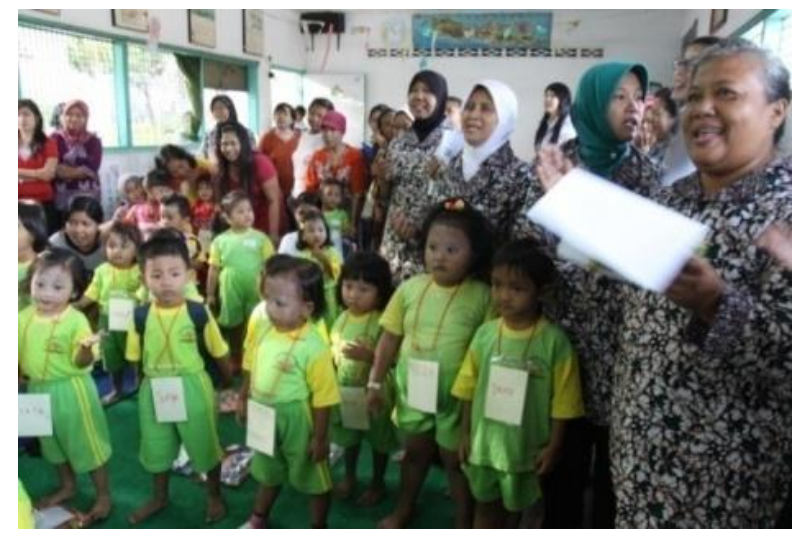

Gambar 15. Para Bunda dan anak-anak PAUD Tunas Cempaka, RW 3 Kelurahan Dr. Soetomo
Sebagian besar dari kegiatan abdimas telah diabadikan, baik berupa foto statik maupun video sebagai dokumentasi. Sementara itu, sejumlah buku pictorial dan alat-alat peraga telah diserahkan untuk memperkaya khazanah bermain dan belajar di PAUD RW 3 "Tunas Cempaka”, Kelurahan Dr. Soetomo.

\section{KESIMPULAN DAN SARAN}

Dengan telah terlaksananya abdimas ini, dapat ditarik beberapa kesimpulan dan saran sbb. :

\section{Kesimpulan}

1. Masih banyak kelembagaan PAUD di daerah "kantong-kantong ketertinggalan sosial" di jantung kota Surabaya yang memerlukan pemberdayaan berbasis komunitas setempat dari pemerintah dengan melibatkan para pakar dari perguruan tinggi. Dengan kata lain, kegiatan abdimas seperti yang dilaporkan di sini adalah bentuk kontribusi nyata perguruan tinggi dalam rangka penerapan IPTEKS tepat guna untuk kemaslahatan masyarakat.

2. Dengan terjalinnya hubungan antara tim pakar perguruan tinggi dengan khalayak sasaran dan para pemangku kepentingan melalui abdimas, tindak lanjut kesinambungan kegiatan pemberdayaan bisa dirancang dan dilakukan, baik dengan dana lokal, dana pemerintah, maupun swadana setempat. Dengan demikian peluang partisipasi penerapan IPTEKS untuk ikut memajukan masyarakat semakin terbuka luas.

3. Inti dari kegiatan pengabdian kepada masyarakat yang dilaporkan di sini adalah mengajak anak-anak PAUD bermain dan belajar dengan materi pokok Bahasa Inggris tematis yang berfokus pada pendidikan karakter. Dengan kegiatan ini telah dihasilkan:

a. Materi bermain dan belajar Bahasa Inggris berfokus pada pendidikan karakter sesuai kebutuhan khusus khalayak sasaran.

b. Demontrasi salah satu bentuk bermain dan belajar kreatif yang dapat menghidupkan suasana kegiatan bermain dan belajar di PAUD.

c. Pendampingan terhadap bunda PAUD yang ujung-ujungnya berdampak pada pemberdayaan dan penguatan wawasan dan kompetensi mereka dalam berkegiatan di PAUD.

d. Bentuk kegiatan yang melibatkan peran aktif para mahasiswa sebagai ajang melatih kepekaan sosial dan soft skills mereka.

e. Penguatan lembaga PAUD pada kelompok sasaran.

f. Upaya nyata menggugah para pemangku kepentingan dan komunitas khalayak sasaran untuk berkontribusi ke arah tercapainya 
"situasi dan kondisi sosial yang lebih ramah dan layak anak".

Kegiatan abdimas yang telah dilaksanakan telah membawa manfaat memberi penguatan, pemberdayaan SDM, dan pencerahan kepada segenap pihak yang secara langsung dan tidak langsung terlibat dalam kegiatan ini.

Ibarat tidak ada gading yang tidak retak, kegiatan pengabdian kepada masyarakat yang telah dilakukan dan dilaporkan ini tak lepas dari berbagai kekurangan di sana sini. Oleh sebab itu bentuk abdimas ini sebagai salah satu prototipe kegiatan abdimas terbuka untuk dikritik yang sifatnya membangun dan perlu terus disempurnakan demi meningkatkan kemaslahatan bersama, khususnya pengembangan khazanah abdimas itu sendiri.

\section{Saran}

Masih banyaknya kelembagaan PAUD di daerah "kantong-kantong ketertinggalan sosial" di jantung kota Surabaya yang memerlukan pemberdayaan berbasis komunitas setempat, diharapkan pemerintah dapat menindaklanjuti melalui kerjasama dengan para pakar dari perguruan tinggi untuk berinovasi dan berkreasi dengan berbagai bentuk kegiatan yang bertujuan mengangkat drajat kualitas sosial mereka, sebagaimana telah dilaksanakan oleh tim abdimas Prodi Sastra Inggris UK Petra.

\section{REKOMENDASI}

Melalui pengalaman bersama khalayak sasaran selama kegiatan berlangsung, Tim mendapat merumuskan beberapa kegiatan tindaklanjut sebagai berikut:

1. Mengadakan pelatihan kompetensi mendongeng cerita-cerita rakyat Nusantara untuk para Bunda PAUD Tunas Cempaka RW 3, Kel. Dr. Soetomo. Kegiatan sekaligus merupakan kegiatan pelatihan calon pelatih Training of Trainer (TOT).

2. Mengadakan kegiatan menghimpun koleksi cerita-cerita rakyat Nusantara yang sangat menonjolkan nilai-nilai kearifan lokal dan pendidikan karakter untuk anak-anak yang bisa disumbangkan kepada bunda PAUD.

3. Mengadakan pelatihan kompetensi mendongeng cerita-cerita rakyat Nusantara untuk kaum ibu yang bisa dipersiapkan sebagai bunda PAUD di wilayah khalayak sasaran dan sekitarnya.

\section{UCAPAN TERIMA KASIH}

Patut disyukuri bahwa Kegiatan abdimas yang didanai oleh Program Hibah DIKTI 2013 yang berjudul ' $\mathrm{I}_{b} \mathrm{M}$ Kompetensi Komunikasi Bahasa Inggris Berbasis Pengembangan Karakter pada Kelompok Belajar Anak di Kelurahan Dr Soetomo, Surabaya", telah bisa dilaksanakan dengan baik pada bulan September dan Oktober 2013. Tim abdimas mengucapkan terima kasih kepada pihakpihak yang memungkinkan kegiatan abdimas ini terlaksana dengan baik, antara lain:

1. Bapak Imam Sudjono, BA, Lurah Kelurahan Dr. Soetomo, Surabaya, yang sangat mengapresisasi kegiatan abdimas dan berkenan memberi arahan demi kelancaran kegiatan.

2. Bapak Gunawan, Wakil Lurah Kelurahan Dr. Soetomo, Surabaya, yang banyak memberi bantuan dan dukungan moral pada taraf perencanaan pelaksanaan kegiatan abdimas.

3. Bapak Ketua R.W. 3, Kelurahan Dr. Soetomo, yang membantu kelancaran kegiatan di komunitas sasaran.

4. Bapak Abraham M. Sitompul, Wahana Visi Indonesia, yang telah banyak memberi masukan karena organisasinya telah banyak melakukan pendampingan di komunitas terkait.

5. Para dosen dan mahasiswa U.K. Petra yang telah bergabung dan berkontribusi dalam pelaksanaan abdimas ini.

6. Para Bunda PAUD Tunas Cempaka, R.W. 3, Kelurahan Dr. Soetomo, yang sangat ramah, terbuka, dan kooperatif demi kelancaran kegiatan abdimas.

7. Warga RW 3, Kelurahan Dr. Soetomo, yang bersikap ramah dan sangat mendukung kegiatan.

8. UK. Petra, khususnya Staf Pusat Pengabdian kepada Masyarakat, yang banyak membantu dari saat perencanaan, pelaksanaan, dan sampai pelaporan hasil kegiatan.

9. DIKTI, khususnya pihak-pihak terkait yang tak mungkin disebutkan satu persatu di sini, yang telah memberikan dukungan dana hibah th. 2013 sehingga abdimas bisa diwujudkan.

Akhirnya, tidak ada gading yang tidak retak. Tim abdimas terbuka untuk menerima kritik-kritik yang membangun sehingga ke depannya bisa menghasilkan bentuk-bentuk kegiatan abdimas yang lebih berhasil-guna dan berdaya-guna bagi penerapan Iptek tepat guna untuk perkembangan masyarakat pada umumnya. 


\section{DAFTAR PUSTAKA}

[1] Jajeli, R. (10 Februari 2012). Banyak Korban Seksual Kontradiktif Predikat Surabaya Kota Layak Anak <http://surabaya.detik.com/read/ 2012/02/10/154421/1839613/466/banyakkorbanseksual-kontradiktifpredikat-surabaya-kotalayak-a nak>

[2] N. A. (11 Nopember 2011). Kasus Kekerasan Anak di Surabaya Tertinggi Jatim, Surabaya Pos Online.
[3] Lickona, T. (1991). Educationg for Character: how our schools can teach respect and responsibility. New York: Bantam.

[4] Kementerian Pendidikan Nasional. (2001). Pedoman Pelaksanaan Pendidikan Karakter. Badan Penelitian dan Pengembangan Kurikulum, Pusat Kurikulum dan Perbukuan. 2011. http//pendikar.dikti.go.id/gdp/wp-content/ uploads/Pedoman-pelaksanaan-Pendikar-18Feb-2011.pdf.

[5] Jaenudin, A. (3 April, 2008). Membangun karakter.<http://www.goodreads.com/story/show/1409 $2>$ 